\title{
Impact of global changes in the business environment in relation to risk management
}

\author{
Katarína Buganová ${ }^{1}$, Jana Šimíčková ${ }^{1,{ }^{*}}$, and Michal Brutovský ${ }^{1}$ \\ ${ }^{1}$ University of Zilina, Faculty of Security Engineering, Department of Crisis Management, \\ Univerzitna 1, 01026 Zilina, Slovakia
}

\begin{abstract}
.
Research background: Entrepreneurial activity is largely affected by negative changes in the global business environment, as evidenced by the huge impact of the COVID 19 pandemic on the entrepreneurial activity of Slovak enterprises. It is here that the importance of proactive risk management is reaffirmed, which should be an integral part of the enterprise's management and thus preventively assess possible risks and their consequences and be prepared to manage them and not just respond to a crisis situation.

Purpose of the article: The purpose of the article is to point out the importance of risk management in business and project management in connection with the globalization of the business environment. Assess the readiness of Slovak enterprises to ensure the continuity of business activities in connection with negative changes in the business environment such as the COVID 19 pandemic.

Methods: The article will be processed using basic scientific methods. The qualitative and quantitative aspects of the researched problem, comparison and generalization of conclusions will be processed through observation, analysis, comparison and synthesis, including several managerial methods for risk assessment and management.

Findings \& Value added: Successful implementation of risk management in the enterprise and within the project activities from the point of view of prevention of crisis situations in the enterprise caused by interruption of operation as well as premature termination of projects is a means to maintain continuity and competitiveness of business activities and achieve project goals in the global market.
\end{abstract}

Keywords: globalisation; changes; risk management; enterprise; continuity

JEL Classification: F64; G32; L26; M21

\footnotetext{
*Corresponding author: jana.simickova@,fbi.uniza.sk
} 


\section{Introduction}

Globalization is also taking on a different dimension in business today, as it is clear that the world will be different once this pandemic has subsided. In particular, changes in the external environment have a major impact on the further development and competitiveness of the enterprise. They affect our behaviour, both customers and manufacturers or service providers. Enterprises face new risks that affect their operability, ensuring the protection of employees' health, as well as investment and development activities in the form of projects. From the point of view of future developments, it is clear that this pandemic is not the last and it is necessary to learn from it and take adequate preventive measures in the future to ensure the continuity of business activities.

Business continuity with regard to prevention aspects can be ensured through integrated risk management into key areas of the enterprise, respectively projects. Risk management should be an important part of corporate governance. Risk management in an environment of globally oriented economies and the internationalization of enterprises is a complex task due to the number of sources of risk, their intensity and interconnection. Risk is usually expressed in terms of sources of risk, potential events, consequences and their probability and is understood as an intentional interaction with uncertainty or the possibility of losing something $[1-3]$.

According to ISO 31000: 2018 Risk management - guidelines, risk management is defined as coordinated activities to direct and control an organization with regard to risk. Risk management includes the identification, assessment and prioritization of risks, followed by the coordinated and economic use of resources to minimize, monitor and control the likelihood or impact of adverse events. Risk management in the enterprise is one of the important internal processes, which strengthens flexibility already in the period of prevention and is necessary to ensure the safety of processes. Risk management focuses on the coordination of activities for the management and leadership of the enterprise with a focus on risks [4 - 6].

In a competitive environment, only those who can assess and manage risks in the enterprise and implement projects effectively and in accordance with the set goals will succeed. In financial markets, risk management is mainly associated with the process of identifying individual risks, their analysis and making investment decisions to reduce the degree of uncertainty of investment decisions. Risk management is a tool for increasing the level of security of implemented activities, processes, projects and overall business activities and is one of the basic tools of managerial decision-making. Good identification and management of risk factors will help projects succeed and increase the confidence of owners and suppliers [7 - 9].

There is also an approach to risk management in projects. The success of projects, whether in the introduction of new technologies, products, expansion of production capacities or change management, can significantly contribute to increasing the competitiveness of the enterprise. Conversely, the failure of projects can lead to a decline in performance, large financial losses or even a threat to the existence of the enterprise, in the case of large investment projects. Due to the fact that each project is defined by a certain degree of uncertainty, there are certain risks associated with each project. Differentiating and reducing risks in today's projects is crucial to the success of the project. Almost every project faces several risks throughout the project timeline. Risks in projects can create unfavorable situations that occur in the process of its implementation with an impact on the overall success of the project. In projects, it is necessary to observe the risk, perceive it, be aware of it, react to it appropriately, manage it and deal with it positively. Risks are an integral part of the project and need to be addressed in a targeted way [10 - 12]. 
There are many definitions of the term project that differ in part. The following can be mentioned as an example. Němec [13] defines a project as a purposeful proposal to carry out a certain innovation in the given start and end-term. Havlík [14] defines a project as a unique process consisting of a series of coordinated and managed activities with a start and end date, carried out to achieve a goal that meets specific requirements, including time, cost and resource constraints.

Project management is a complex discipline that has become one of the most widely used tools for the development and delivery of unique products and services, which has spread across a huge number of enterprises. Project management is currently an important part of the business world and its implementation is planned or implemented by many enterprises. One of the pillars of successful project management is also implemented risk management. Project risk management is an integral and essential component of project management. It is necessary to evaluate each project separately with regard to risks, as it can bring with it specific risks. Their creation is associated with the financial complexity of projects, the non-repeatability of projects as well as a longer time frame for implementation. Project risks also mean possible negative situations that are produced in the process of its implementation with an impact on the overall success of the project. Improper assessment and reactive management of related risks usually results in cost overruns, schedule delays and quality problems [15].

Projects are threatened by a number of different risks, which result from the nature of the dynamically changing internal and external environment of their implementation. Risks accompany every project and are part of all stages of its life cycle. In the area of project risk management, it is necessary to develop an integrated and comprehensive approach to risk management for each enterprise. The priority areas of risk analysis in the implementation of the project are: determining the probability of occurrence of risk, qualitative identification of risks, determining the size of probable losses taking into account the risks, the development of risk mitigation. In general, risky business leads to increases leading to a lack of external sources of funding. Isolating project risk from business management systems is a weakness of the enterprise's operation. The integration of project risk management processes into the overall management system and especially into risk management strategies makes a significant contribution to improving the organizational culture [16 - 19].

\section{Methods}

The effects of the COVID 19 pandemic can be seen in all areas of business and social life. As a result of COVID 19, the EU-27 countries have introduced a wide range of restrictive measures, such as working from home for employees, stopping or cancelling planned events and projects, imposing travel bans and, in some cases, even stopping production altogether. This has had a significant impact on the economy, which has put many businesses in a precarious situation. These measures have generally had a negative impact on demand and thus on production in many areas. In the OneAcadiana [20] survey at the time of the peak of the pandemic, which was attended by 1000 respondents, it is stated how the COVID-19 pandemic affected business activities in various areas (Fig.1). Respondents encompassed a variety of types, industries, and sizes of businesses. 


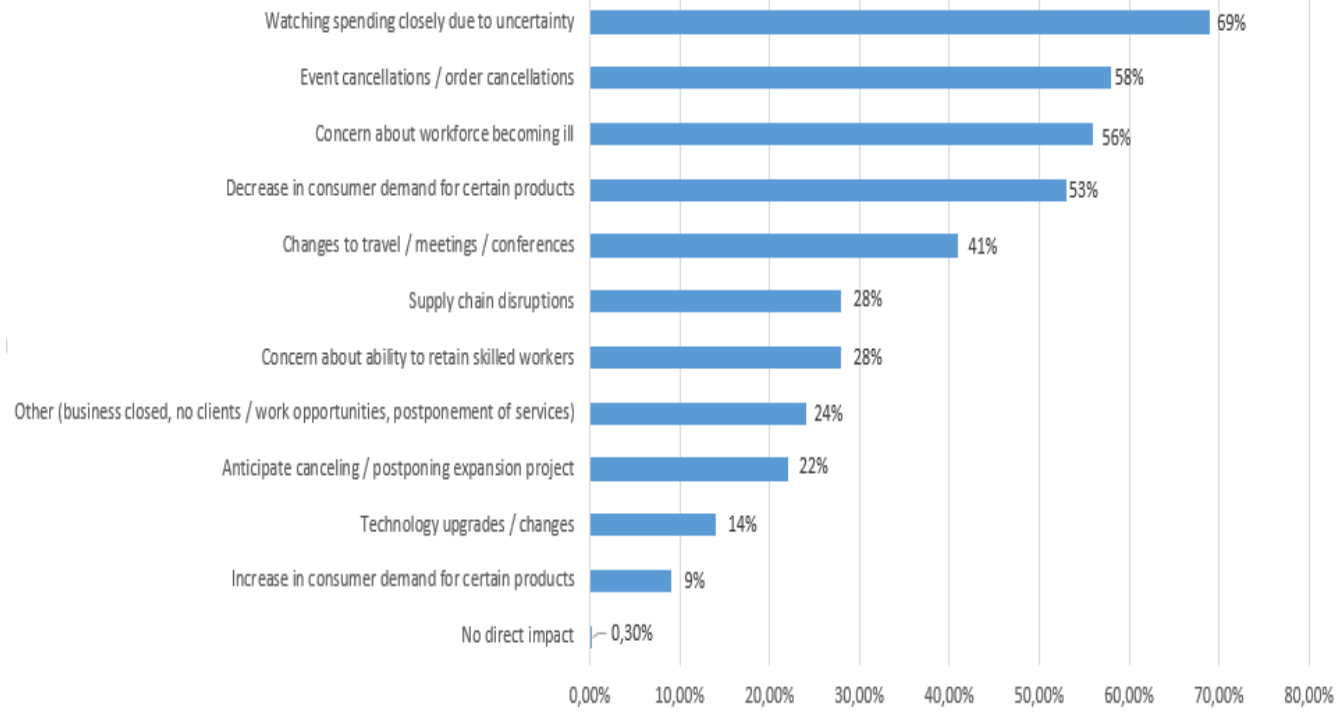

Fig. 1. Changes in the business environment caused by the COVID 19 pandemic, adjusted according to $[20]$.

In addition to the results shown in Fig. 1, to $91 \%$ of respondents expected a drop in income and $72 \%$ of all respondents said they expected a significant drop in revenue. The majority of respondents had problems with the cancellation of orders and reduced demand $(58 \%)$. As a result, they had to start reducing their expenses and adjusting their work plans. $35 \%$ of enterprises reduced the number of employees or planned to do so. On average, $64 \%$ have already reduced operating hours, working hours or reduced wages, increasing to $88 \%$ for those enterprises that responded on the last day of the survey. $22 \%$ cancelled planned investment and project activities. Almost half of the enterprises were not sure how long they would last in the given economic conditions [20].

Evidence that the crisis caused by the COVID 19 pandemic has affected all industries is the Eurostat survey, which shows the rate of development of selected industries in the EU between March and April 2020, during the COVID 19 pandemic (Table 1).

Table 1. Rate of development of industrial production in selected industries in the EU during the COVID 19 pandemic, adjusted according to [21].

\begin{tabular}{|c|c|c|c|c|c|c|c|}
\cline { 2 - 7 } & $\begin{array}{c}\text { Motor } \\
\text { vehicles, } \\
\text { trailers, } \\
\text { semi- } \\
\text { trailers }\end{array}$ & $\begin{array}{c}\text { Leather } \\
\& \\
\text { related } \\
\text { products }\end{array}$ & $\begin{array}{c}\text { Wearing } \\
\text { apparel }\end{array}$ & $\begin{array}{c}\text { Computer, } \\
\text { electronic } \\
\text { \& optical } \\
\text { products }\end{array}$ & $\begin{array}{c}\text { Pharmaceutical } \\
\text { products }\end{array}$ & $\begin{array}{c}\text { Tobacco } \\
\text { products }\end{array}$ & $\begin{array}{c}\text { Total } \\
\text { industry }\end{array}$ \\
\hline $\begin{array}{c}\text { March } \\
\mathbf{2 0 2 0}\end{array}$ & $-33,5 \%$ & $-40,4 \%$ & $-32,8 \%$ & $4,1 \%$ & $16,9 \%$ & $4,6 \%$ & $-10,9 \%$ \\
\hline $\begin{array}{c}\text { April } \\
\mathbf{2 0 2 0}\end{array}$ & $-68,5 \%$ & $-60,2 \%$ & $-30,4 \%$ & $-5,0 \%$ & $-11,9 \%$ & $0,6 \%$ & $-17,3 \%$ \\
\hline
\end{tabular}

As can be seen, in March 2020, EU industrial production fell by 10,9\% compared to February 2020 and by $12,2 \%$ compared to March 2019. The decline continued in April 2020, when EU industrial production fell by 17,3\% compared to March 2020 and 27,2\% compared to April 2019. For the various industries, the sector with the largest decline in production in March and April 2020 was motor vehicles, followed by the production of leather goods and clothing. Pharmaceutical products increased by 16,9\% in March, which 
decreased by $-11,9 \%$ in April. In March, compared to February 2020, the largest decreases were recorded in Italy $(-28,4 \%)$, Slovakia $(-20,3 \%)$ and Luxembourg $(-19,8 \%)$. In April, compared to March 2020, industrial production fell in all Member States, with the largest decreases in Hungary (-30,5\%), Romania (-27,7\%) and Slovakia (-26,7\%) [21].

The negative impact of the pandemic also spread across the branches of the Slovak industry. Slight year-on-year output growth was maintained only by food producers $(0,8 \%)$, supported by increased food demand due to household frontloading at the beginning of March 2020, and electrical equipment producers, who also showed a significant slowdown in double-digit growth from double-digit levels in previous months. The month-on-month and year-on-year decline in industrial production in Slovakia was the third-worst in the EU in April 2020. Month-on-month, the Slovak industry weakened by $26,7 \%$ and year-on-year by $42 \%$ [22].

In Slovakia, ultimately, the crisis in the most important sector in the automotive industry affects $50 \%$ of industrial production, including a number of smaller enterprises. These companies are connected not only to Slovak car manufacturers. Components made in Slovakia usually travel to customer plants of various manufacturers in Europe, Asia and North America. And it is the automotive industry that is probably experiencing the biggest crisis in history due to the COVID 19 pandemic. Carmakers and their wide supply network around the world will primarily struggle with the restart of production. The key question that manufacturers will then ask is how consumers' shopping behaviour will change. Europe - a decrease of about 13,6\% (1,9 million vehicles produced). The expected production for 2020 is 15,6 million vehicles. Europe is currently one of the regions most affected by the COVID 19 pandemic [23].

Based on the above, it is first and foremost necessary to focus in the future in all sectors on ensuring the safety and health of its employees. Slovak enterprises will have to implement all the necessary measures required by the newly adopted legislation and will also be pushed by customer audits to ensure production from the point of view of safety and health protection at the same level as larger employers. It is also necessary to focus on the prevention and ensuring the operability of enterprises as well as the thawing of investment and project activities. It is here that we get to the possibility of applying an increase in the security of business activities as well as project activities by implementing risk management according to current standards and regulations.

\section{Results}

Business management is one of the most challenging missions or challenges that a person chooses during their managerial career. It represents the personal success of the manager and a great deal of responsibility towards superiors and subordinates in the corporate structure of employees and the whole environment in the area of his work. Fulfilling the basic functions of management, which are planning, organizing, leading, managing, motivating and controlling, requires adequate knowledge, skills and the ability to decide on the efficient use of resources. For a manager to fulfil all these preconditions as a moral and not a formal authority in a enterprise, he must make sufficient use of and implement risk management in the enterprise.

Recent events have revealed not only the limits of enterprises and corporate management, but above all their strengths and weaknesses and their readiness to respond to unforeseen changes in the environment. It is here that the importance of proactive risk management is reaffirmed, which should be an integral part of the enterprise's management and thus preventively assess possible risks and their consequences and be prepared to manage them and not just respond to a crisis situation. Enterprises must improve their preparedness for how to deal in the future with possible negative changes in the 
environment (sources of risk) that may lead to a crisis situation. On the other hand, strengths need to be strengthened and opportunities and development projects must be focused on.

The historically used procedure in the common understanding of man from standard to above standard, from the simplest and cheapest (to do now) to more complex and more expensive (to postpone until later) also applies to the project management of the enterprise. This rule should also apply to prevention, the area of risk prevention and minimization or elimination, where prevention is usually always more readily available and cheaper than repression. It is often not visible and tangible, especially if the project course of activities is smooth and the enterprise is doing well (trade boom). However, everything begins to change only when the opposite state occurs and prosperity ceases (recession).

At the same time, we forget that the directive of the Council of the European Union no. $89 / 391$ / EEC states that the employer must be able to identify and assess risks to safety and health, identify and take the necessary protective measures. When planning risk prevention in enterprises, it is necessary to take into account the impact of technology, work enterprise, working conditions, social relations and the impact of the environment on the workplace.

Risk management and crisis management interact with each other. If we focused only on the reactive phase of crisis management, then its task would be to respond to the crisis. The proactive phase, on the other hand, is part of risk management. However, risk management and crisis management of a enterprise can also be perceived as parallel processes, which take place simultaneously in the phase of prevention against corporate and economic crises.

Preparation for dealing with the consequences of crisis phenomena is carried out through crisis planning, which is a function of crisis management. Tasks aimed at crisis prevention and finding suitable forms of risk minimization are solved by risk management. All steps in this process should be assessed in three respects: financial, administrative and technical. The division of the risk management preparedness process into two sub-threads, which are interconnected by the assessment and planning phase, is justified. Risk prevention is an unconditional risk, and the realization of unconditional risk is an accidental event and is not subject to any other risks. However, crisis preparedness refers to a potential risk that can only be taken into account if we assume that some previous risk has materialized.

In this context, it is possible to use current standards as a basis for implementation, which, however, are only recommendatory in the case of risk management. The basis for the implementation of the risk management system into management systems should be process-oriented management in accordance with the quality management system. Systematic optimization of the interaction of processes in terms of a management system with clearly defined responsibilities and communication and control tools is a prerequisite for the enterprise to achieve the set goals [24].

The advantage the implementation of the ISO 31000: 2018 Risk management Guidelines standard is its complexity and applicability in all processes carried out in risk management, as well as its applicability for all types of enterprises from the private to the public sector. Risk management process, it is risk and opportunity management, which is set out in ISO 31000: 2018 Risk management - Guidelines, consists of 6 main stages (scope, context, criteria; risk assessment; risk treatment; recording and reporting; communication and risk monitoring). The risk assessment includes risk identification, analysis and evaluation. In Fig. 2 shows the process of risk management according to ISO 31000 and crisis management in relation to each other as crisis prevention and crisis response. 


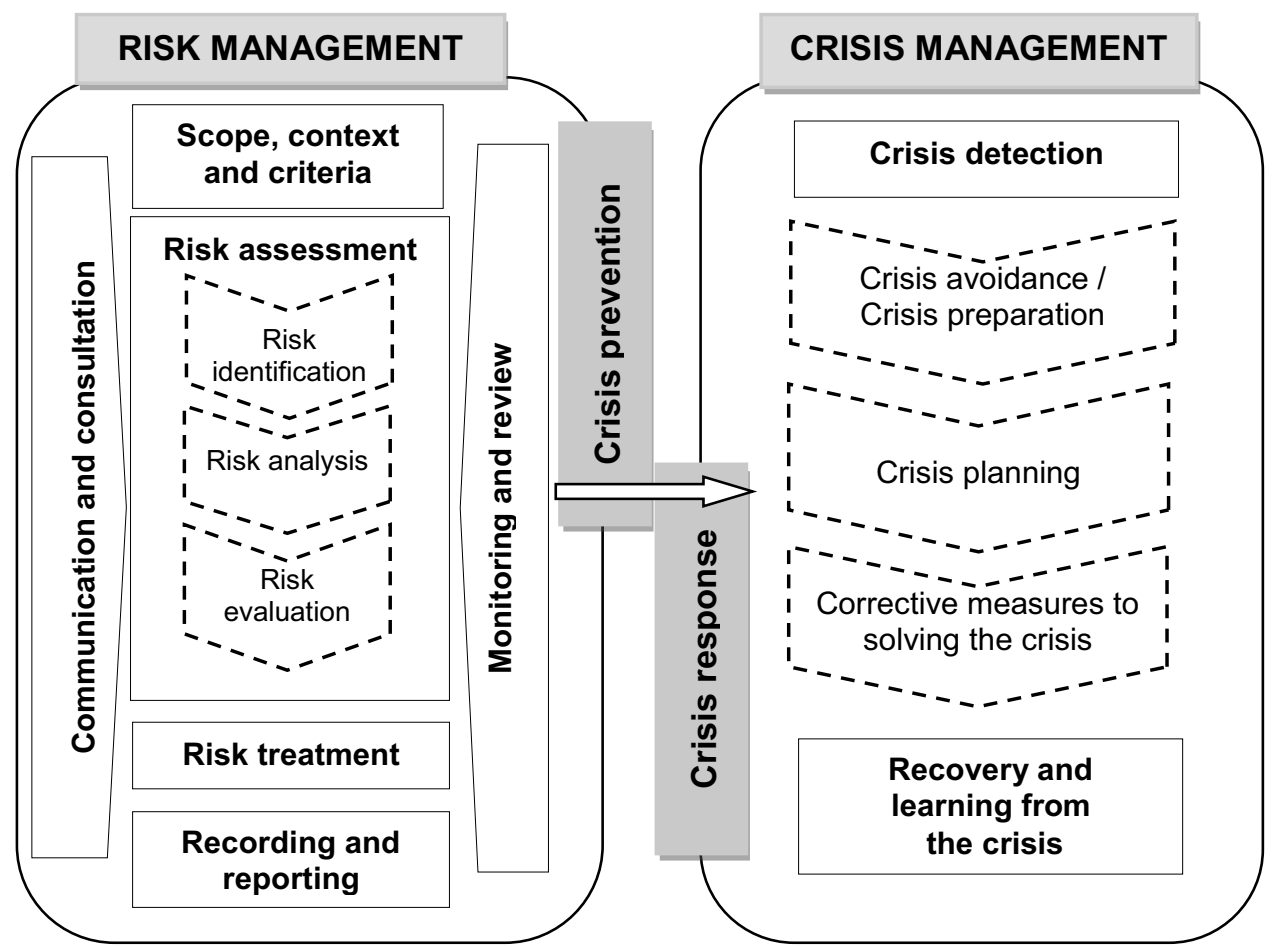

Fig. 2. The process of risk management and crisis management in a mutual relationship, adjusted according to [25].

The risk management framework according to ISO 31000: 2018 consists of understanding the internal and external relationships of the enterprise, creating risk management policy, integrating risk management into business processes, defining responsibilities, allocating resources for risk management, determining tools for internal and external communication and reporting. Its usability in the business activities of enterprises is supported by a wide range of methods and techniques used in individual phases of the risk management process. These methods are available in ISO 31010: 2019.

This process can be applied to all types of risks from business, through environmental to the protection of life and health at work, etc., provided that adequate procedures and methods are used and the legislative requirements in the given area of risk assessment. ISO 31000: 2018 Risk management - Guidelines and its connection to project management can also be found in the standard ISO 21500: 2012 Guidance on project management. All risk management activities related to project management are based on the ISO 31000 process, which includes the systematic application of policies and procedures to communication and consultation activities, context determination and evaluation, processing, monitoring, control, recording and reporting of risks and other process elements. The risk management process should be an integral part of management and decision-making and should be integrated into the structure, operations and project management processes of the enterprise.

\section{Discussions and conclusion}

The established and managed risk management process with a systematic approach to work is a prerequisite for increasing the success of the implemented activities of enterprises in terms of risk and sustainable development. The intention is to deal with risk assessment and 
reduction to minimize the negative consequences of risk events. The causes of foreseeable risk events can be influenced, therefore in some cases, it is possible to mitigate their negative impact by adequate measures. Otherwise, the management of the company or project should have prepared scenarios to minimize and manage the negative consequences that may take the form of a crisis.

Raising awareness of the possibilities and approaches to risk management and crisis management in corporate management as well as project management supports the success of implemented activities, development and expansion of the level of knowledge of all stakeholders. The victors of the crisis are those who are prepared and able to adapt to negative changes in the environment efficiently and flexibly. It is necessary to start from the readiness and responsibility of individuals and from solving problems in all respects to building a business strategy. Because even though the adequacy of the implementation of risk management and crisis management into management systems is obvious, there are still very few enterprises in Slovakia that use this option. And the fact that we can overcome one crisis will not guarantee any enterprise success in the future if it does not approach risk management as the prevention of crises systematically.

Publication of this paper was supported by Cultural and Educational Grant Agency of the Ministry of Education, Science, Research and Sport of the Slovak Republic - 026ŽU-4/2020 KEGA Innovation and internationalization of teaching as a tool to improve the quality of education.

\section{References}

1. Hudakova, M., Luskova, M. (2016). Global environment impacts on enterprise risk management. In T. Kliestik (Ed.), 16th International Scientific Conference on Globalization and its Socio-Economic Consequences (pp. 694-701). Rajecké Teplice.

2. Nedeliakova, E., Hudakova, M., Masar, M., Lizbetinova, L., Stasiak-Betlejewska, R., Sulko, P. (2020). Sustainability of Railway Undertaking Services with Lean Philosophy in Risk Management-Case Study. Sustainability, 12(13), 5298.

3. Ristvej, J., Lacinak, M., Ondrejka, R. (2020). On Smart City and Safe City Concepts. Mobile networks \& applications, 25(3), 836-845.

4. Tranchard, S. (2018, February 15). The new ISO 31000 keeps risk management simple. ISO. Retrieved from : https://www.iso.org/news/ref2263.html

5. Hubbard, D. W. (2009). The failure of risk management: Why it's broken and how to fix it. John Wiley \& Sons.

6. ̌̌ehák, D., Šenovský, P., Hromada, M., Pidhaniuk, L., Dvořák, Z., Loveček, T., Ristvej, J., Leitner, B., Sventeková, E., Mariš, L. (2018). Metodika hodnocení resilience prvku kritické infrastruktury. Ostrava: VŠB-Technická univerzita Ostrava, Fakulta bezpečnostního inženýrství.

7. Jonek-Kowalska, I. (2019). Efficiency of Enterprise Risk Management (ERM) systems. Comparative analysis in the fuel sector and energy sector on the basis of Central-European companies listed on the Warsaw Stock Exchange. Resources Policy, 62, 405-415.

8. Pfeiferová, D. Kuchařová, I. (2020). Risks of collective investment undertakings in the context of global capital markets. In T. Kliestik (Ed.), 19th International Scientific Conference Globalization and Its Socio- Economic Consequences - Sustainability in the Global-Knowledge Economy. Rajecké Teplice.

9. Pflueger, C., Siriwardane, E., Sunderam, A. (2020). Financial market risk perceptions and the macroeconomy. Quarterly Journal of Economics, 135(3), 1443-1491. 
10. Shepherd, DA., Patzelt, H., Berry, CM. (2019). Why Didn't You Tell Me? Voicing Concerns ver Objective Information About a Project's Flaws. Journal of Management, 45(3), 1087-1113.

11. Lovecek, T., Ristvej, J., Sventekova, E., Siser, A., Vel'as, A. (2016). Currently Required Competencies of Crisis and Security Managers and New Tool for Their Acquirement. In H. Zhang (Ed.), 3rd International Conference on Management Innovation and Business Innovation, 5, (pp. 3-8). Manila.

12. Soltes, V., Stofkova, KR., Lenko, F. (2020). Socio-economic consequences of globalization on the economic development of regions in the context of security. In T. Kliestik (Ed.), 19th International Scientific Conference Globalization and Its SocioEconomic Consequences - Sustainability in the Global-Knowledge Economy. Rajecké Teplice.

13. Němec, V. (2012). Projektový management. Praha: Grada Publishing.

14. Havlík, J. (2004, September 14). ISO 10006, Směrnice pro management jakosti v projektech. ANZDOC. Retrieved from: https://adoc.pub/iso-10006-smrnice-promanagement-jakosti-v-projektech-jan-ha.html

15. Gaudenzi, B. Qazi, A. (2020). Assessing project risks from a supply chain quality management (SCQM) perspective. International journal of quality \& reliability management.

16. Chechenova, L.M., Volykhina, V.N, Egorov, Y.V. (2020). Alternative approach to analysis of risks affecting the efficiency of implementing the investment project in the conditions of global instability of economic space. In T. Kliestik (Ed.), 19th International Scientific Conference Globalization and Its Socio- Economic Consequences - Sustainability in the Global-Knowledge Economy. Rajecké Teplice.

17. Toth, M., Rabek, T., Strapekova, Z. (2020). Impact of Integration and Globalization on Business Risk and loans in Slovak Agriculture. In T. Kliestik (Ed.), 19th International Scientific Conference Globalization and Its Socio-Economic Consequences Sustainability in the Global-Knowledge Economy. Rajecké Teplice.

18. Parashkevova, E. (2020). Integrating project risk into risk management strategies in public sector organization. In F. Uslu (Ed.), 7th International conference on education and social sciences (pp. 754-764). Dubai.

19. Soltes, V., Kubas, J., Stofkova, KR. (2017). Possibilities of financing the selected level of education in municipalities. In L. G. Chova, A. L. Martinez \& I. C. Torres (Eds.), 10th Annual International Conference of Education, Research and Innovation (pp. 8729-8734). Seville.

20. OneAcadiana (2020, March 25). COVID-19 Business Impact Survey. OneAcadiana.org.

Retrieved from

https://www.oneacadiana.org/sites/default/files/PDFs/COVID19_Business_Impact_Sur vey_Slides_(040120_v6).pdf

21. Eurostat (2020, June 10). Industrial production down in March and April 2020. Eurostat. Retrieved from : https://ec.europa.eu/eurostat/web/products-eurostat-news//DDN-20200612-2

22. Trend (2020, May 13). Slovensko a svet: Pandémia koronavírusu zasiahla slovenský priemysel. Trend.sk. Retrieved from: https://www.trend.sk/trend-archiv/slovenskosvet-pandemia-koronavirusu-zasiahla-slovensky-priemysel

23. Žákovič, M. (2020, April 20). Ako kríza automobilového priemyslu ovplyvní slovenské firmy. Podnikajte.sk. Retrieved from: https://www.podnikajte.sk/manazment-astrategia/kriza-automobiloveho-priemyslu-slovenske-firmy 
24. Hudakova, M., Dvorsky, J. (2018). Assessing the risks and their sources in dependence on the rate of implementing the risk management process in the SMEs. Equilibriumquarterly Journal of Economics and Economic Policy, 13(3), 543-567.

25. Šimák, L. (2016). Krizový manažment vo verejnej správe. Žilina: Žilinská univerzita. 